\title{
Evolution Sustainable Development Approach From Islamic Based Development Perspective
}

\author{
Ahmad Nazrul Alif Yahya ${ }^{1}$, Baihaki Bin Abdullah ${ }^{2}$, Muhamad Hazrin \\ Sayuti $^{3}$ \\ \{nazrul_alif@ymail.com¹, baihakiusm@gmail.com², ayeinhaz@yahoo.com³ \\ Centre for Islamic Development Management Studies (ISDEV) Universiti Sains \\ Malaysia $^{123}$
}

\begin{abstract}
This paper purpose of analyzing the evolution of a sustainable development approach from an Islamic perspective. In general sustainable development is a development that meets current and future needs to achieve sustainability between economic, social and environmental development without affecting the needs of the next generation. Sustainable development has been highly regarded in development disciplines after severe pollution in the first world countries. The question is, the evolution of this sustainable development approach characterized by Islamic-based development? This paper has two objectives. First, to identify the evolution of a sustainable development approach. Second to analyze and formulate the evolution of sustainable development approach according to Islamic-based development. This analysis was done using by library method and content analysis. The evolution of the sustainable development approach is found to encompass the environment and economic growth only. This evolution is more comprehensive when it can be done from an Islamic perspective that involves a relationship with Allah SWT.
\end{abstract}

Keywords: Evolution, Development and Islamic based sustainable.

\section{Introduction}

In general sustainable development is a development that meets current and future needs to achieve sustainability between economic, social and environmental development without affecting the needs of the next generation (1),(2). Sustainable development has been highly regarded in development disciplines after severe pollution in the first world countries (3). The human thought to the environment, economic and social development is changing time by time. At the end of the 1980s, human concerns arose when assessing natural development and their relationship to the environment, quality of life, economic development was changed. This assessment has opened a new approach to environmental issues (4). This approach purpose of balancing human demand for natural resources and the natural resources of the economy. This approach is called sustainable development. The question is, the evolution of this sustainable development approach in line with Islamic-based development? This paper intends to identify the evolution of a sustainable development approach. Then this paper analyzes and summarizes the evolution of sustainable development approach based on the perspective of Islamic-based development. The discussion of this paper focuses on the definition of sustainable development, the evolution of a sustainable development approach, the chronology of sustainable development concepts and the principles of sustainable development. 


\section{Theoritical}

\subsection{The Sustainable Develpment}

Development means the process of translating or describing design spesification into physical features (5),(6). Specifically development not only in needs analysis, but also in broad issues regarding preliminary analysis, such as contextual analysis (7). Meanwhile, Unesco, (2002) states sustainable development is defined as a development that is implemented without dispose of resources and eco-friendly (8),(9). The sustainable development is one of the support measures to preserve the living system so that these people and other living beings can continuously channel their needs in the future. the balance is given emphasis on nature to reduce the exploitation of natural resources. Consequently, sustainable development is a concept of progress that sustains natural resources to be utilized by future generations (10).

The real definition of sustainable development is more likely to be defined in the world commission of environment and development (Wced). Wced provides the definition of sustainable development as 'the necessity of a development activity to be implemented without compromising the need for future generations'. The Need Here Is To Refer To The Environment, Economy And Social (11),(10).

The concept of sustainable development is the most proactive and practical modern development to address environmental development and conservation issues. This concept was triggered during the earth summit in Rio in 1992. However, the sense of sustainable development is still blurry and can be defined differently in different situations and needs according to perspectives and ideologies translated by certain parties (12),(11). This distinction is based on the different views of the economy, the environment, the social science, the pure science and so forth (13).

According to (14) sustainability will be achieved when essential principles such as peace, justice, and good governance (14). All these definitions show the importance of balance between human needs for wellbeing by maintaining environmental resources and ecosystems (2). Most of the definitions of sustainable development cover three main ideas that are mutually dependent on each other - environmental, economic and social. Three ideas in the form of circles that are thought to be interconnected with each other (15). In other words, these three ideas should be balanced as shown in figure 1 . 


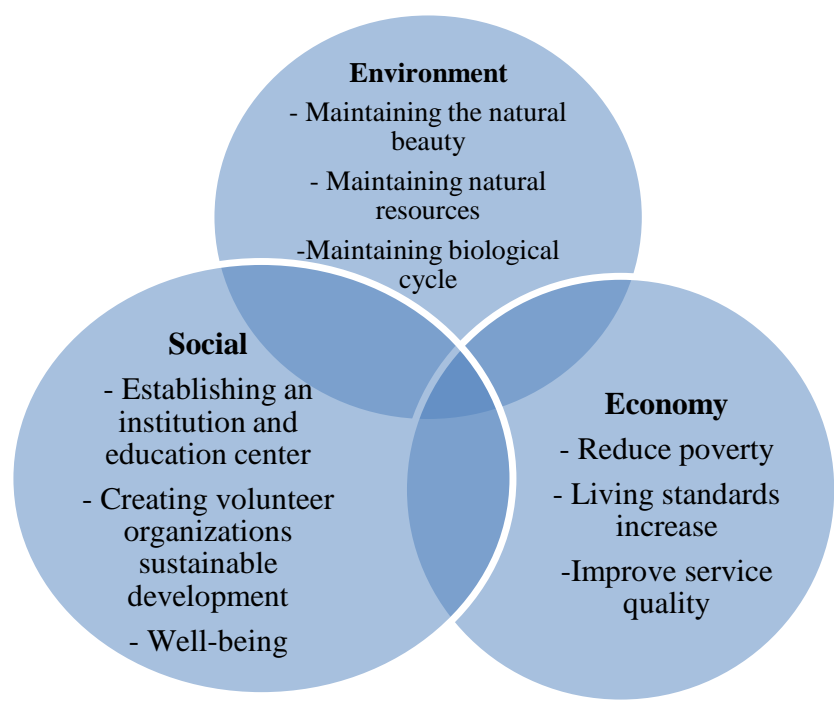

Sources: [2]

Fig.1. Sustainable Development Idea

Figure 1 shows the idea of sustainable development presented which encompasses three aspects namely environment, economy and social (15). Environmental aspects describe the retention of natural beauty, natural resources and biological cycles. The economic aspect emphasizes poverty alleviation, improving living standards and improving service quality. Social aspects emphasize establishing institutions and education centers, creating volunteer organizations for sustainable development and well-being.

\subsection{Evolution Of Development Sustainable Approach}

The formal concept of sustainable development emerged through the 1980s as an integrated approach and various fields. anxiety arises when an environmental exploitation occurs (11). This has led to a deterioration in economic development and quality of life. This relationship approach is observed on a global scale, country and country to create a framework where people can understand and consequently influence the direction of economic development in developed countries and developing countries. The idea of sustainable development was first introduced at the world conservation strategy (1980) sponsored by the international union for the conservation of nature (IUCN).

This first explosion asserts sustainability or maintains exclusively from an ecological point of view and ignores economic development. The main stresses are the preservation of ecological processes, the continuation of natural resources and the preservation of genetic diversity. This stress only emphasizes the physical well-being of the environment. This formulation looks at environmental-economic relations only from the point of human impact on the environment and reflects all the impression is negative.

Salvage views that there is a relationship between the level of environmental pollution and the economic progress of a country (16). The more developed the country is, the greater 
the environmental problem faced. This relationship is shown based on rostow growth stage in figure 2 .

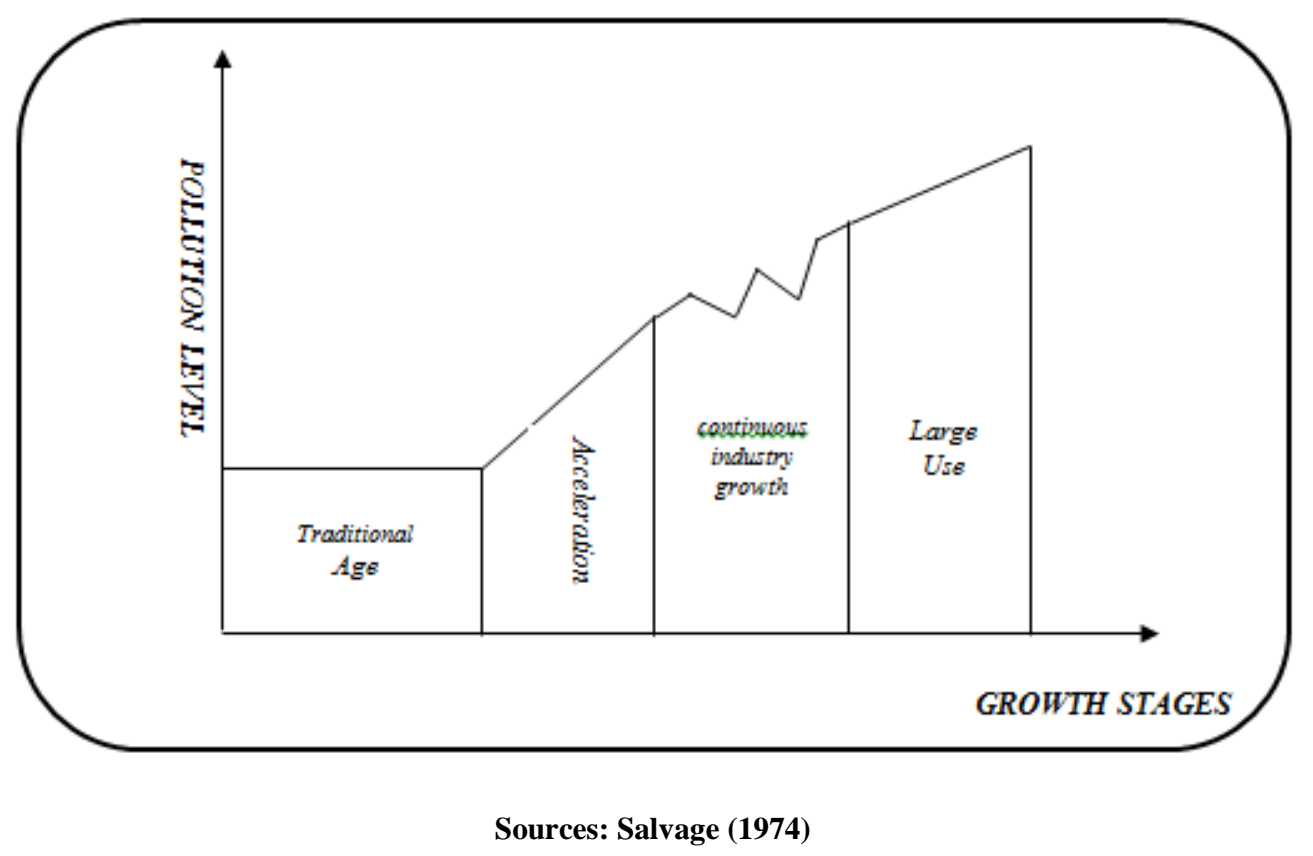

Fig.2. Progress Of Level Of Progress And Pollution Level

Figure 2 shows the correlation level of progress with the level of pollution. Based on this figure, Salvage (1974)(17) shows that It has a direct relationship with economic growth (16).

Economic development is also important in improving the welfare of society as a whole. However, if the quality of the environment is neglected, it will cause the welfare of society to decline. Less understanding of the relationship between the economy to the environment has resulted in a 're-formulation' of sustainable development concept. This re-formulation has influenced the establishment of the world commission on environment and development commission (wced) in 1984 or better known as the brundtland commission. The commission has initiated several studies that publish 'our common future' (18). This report has put a benchmark for all future discussions on sustainable development.

This Brundtland Report Defines Sustainable Development As: "...Development Is A Necessity In A Country Where Its Implementation Does Not Affect The Needs Of Future Generations....". This report gives different perceptions of economic development, with growth quality seen as equally important with quantity of growth. This report illustrates that humans can put values on the physical environment through certain forms of environmental management (11). 


\section{Method}

Qualitative methods were used in this study. The study data is obtained by review literature [8]. Referenced documents are related to development principles in Islam.

\subsection{Result and Discussion}

Evolution Of The Sustainable Development Approach From Islamic Perspective

Overall, the evolution of this sustainable development approach is more towards western development or is known as a common development. The evolution of this sustainable development approach is formed when there is pollution in the first world countries. It is more pressing on the care of the environment and the natural resources. The philosophy of evolution of this sustainable development is more to the western philosophy of environmental concern and economic growth.

According to (18), Sustainable development is a development that meets the latest needs without affecting the ability of future generations to meet their needs (18). However, the definition is the simplest way to simplify a complex issue and lead to a difficult to measure (19).

This suggests that the environment is very important as it can lead to the economic growth of a country. This natural resource needs to be maintained to meet the needs of future generations. This argument can be backed up when Unesco (2002) issued a sustainable development statement is one of the support measures to safeguard the life system so that these humans and other living beings can continuously channel their needs in the future. The balance is given emphasis on nature to reduce the exploitation of natural resources (9).

It is evident that the evolution of this sustainable development approach is more concerned with the environment and related economic growth. The three interconnected, environmental, economic and social links are the philosophies used by western countries to shape sustainable development.

Contrary to Islamic epistemology and Islamic tasawur which explains the illustration of an essential islamic form and explains the overall fundamental principles of Islam (20). According to the epistemology and islamic tasawur, the environment is a creature. States that god s.w.t is the creator and absolute owner of the universe. Humans are only given the responsibility of managing the natural resources (21).

This islamic-based development is more sustainable to implement development because it has the principles of development that are in accordance with its standards. According to Islamic-based development has seven principles relating to development (22). The seven principles of development are seven principles such as molds, perpetrators, time scales, frameworks, methods, tools and islamic-based development goals.

Sustainable development formed between 1970 and 1997 is a great effort to keep the environment from running out of resources. It is not wrong even when economic growth is an important thing for every country that wants to move forward. however, every creature born in this earth, allah swthas placed a provision on everyone. This means the natural resources required by the next generation will exist, and there is still a resource that can be used for future generations. Indirectly three things like economic, social and environmental will depend on each other. 


\section{Conclusion}

The discussion of this paper argues that the evolution of this sustainable development approach is designed for the maintenance of natural resources and economic organizations solely. The establishment of sustainable development is very good and serves as a guide for every country to develop the country. It is better than this sustainable development is done with Islamic-based development so that the real goal of development can be achieved.

\section{References}

1. Fatimah, Y. A., \& Biswas WK (2016). Remanufacturing as a means for achieving low-carbon SMEs in Indonesia. Clean Technol Environ Policy. 18(8):2363-2379.

2. Rekarti E, Bahari Z, Zahari NM, Doktoralina CM, Ilias NA. The sustainability of muslim women entrepreneurs: A case study in Malaysia. Int J Financ Res. 2019;10(5):430-9.

3. Redclift M. Sustainable development: Exploring the contradictions. Routledge; 2002.

4. Fauza AG, Khairulmaini OS. The growth of cities, environmental decay and the impact on the urban poor: experiences and lessons from the city of Kuala Lumpur. Cities in the. 2000;21(June):24-44.

5. Richey RC. Research on instructional development.Educational Technology Research and Development. Vol. 45. 1997. 91-100 p.

6. Richey, R. C., \& Klein JD. Design and development research: Methods, strategies, and issues. Routledge; 2014.

7. Tessmer, M., \& Richey RC. The role of context in learning and instructional design. Educ Technol Res Dev. 1997;54(2):85-115.

8. Collison, D., Ferguson, J., \& Stevenson L. Sustainability accounting and education. In Sustainability accounting and accountability. Routledge. 2014;48-66.

9. UNESCO. Lessons learnt from a decade of commitment. World Summit on Sustainable Development. [Internet]. Paris; 2002. Available from: portal.unesco.org

10. Mudacumura, G. M., Mebratu, D., \& Haque MS. Mudacumura, G. M., Mebratu, D., \& Haque, M. S. (2017). Sustainable development policy and administration. Routledge. 2017.

11. Mudacumura GM. Toward a general theory of sustainability. In Sustainable Development Policy and Administration . Routledge. 2005. 157-188 p.

12. McManus P. Contested terrains: politics, stories and discourses of sustainability. Env Polit. 1996;5(1):48-73.

13. Zain, S. M., Badaruzzaman, W. H. W., Elfithri, R., Basri, N. E. A., Khatimin, N., Zaharim, A., \& Suja F. Kaji Selidik Pendidikan Alam Sekitar Dan Keperluan Kepada Pembangunan Lestari Dalam Proses Pengajaran Dan Pembelajaran Di Fakulti Kejuruteraan Dan Alam Bina. In Seminar Pendidikan Kejuruteraan dan Alam Bina (PeKA ’09) . Malaysia. 2009;44-60.

14. Banister D. The sustainable mobility paradigm. Transp Policy. 2008;15(2):73-80.

15. Barbier EB. The concept of sustainable economic development. Environmental Conservation. 1987;14(2):101-10.

16. Mebratu D. Sustainability and sustainable development: Historical and conceptual review. Environ Impact Assess Rev. 1998;18(6):493-520.

17. Salvage JW. Investigation of secondary flow behavior and end wall boundary layer development through compressor cascades. NASA STI/Recon Technical Report N, 75. 1974.

18. WCED. Development and International Economic Co-Operation: Envirinment. English. 1987; Available from: sswm.info/sites/default/files/reference_attachments/UN WCED 1987

Brundtland Report.pdf 
19. O'Reilly K, Paper D, Marx S. Demystifying grounded theory for business research. Organ Res Methods. 2012;15(2):247-62.

20. Doktoralina CM, Bahari Z, Abdullah SR. Mobilisation of Income Zakat Payment In Indonesia. Ikonomika [Internet]. 2018;3(2):179-194. Available from:

https://doi.org/https://doi.org/10.24042/febi.v3i2.3659

21. Chapra MU. Islam and the economic challenge (Islamic Economics Series, 17). Hemdon, VA: International Institute of Islamic Thought. 1992.

22. Salleh MS. Tujuh prinsip pembangunan berteraskan Islam. Zabra Editions Sdn. Bhd. 2003. 